\title{
CROSSING BORDERS AND TRANSFORMING IDENTITIES: \\ ENCOUNTERING DIASPORIC MEXICANNESS \\ IN AUSTRALIA
}

\author{
GABRIELA CORONADO
}

$\mathrm{N}$ ational borders and identities are interrelated in complex, dynamic and dialogic ways. When one moves to livein a new country, there is a tendency to believe that by crossing different borders (whether concrete and symbolic, spatial, linguistic or cultural), theoriginal cultural identity is at risk of disappearing because of the need to be accepted by the recipient country and the pressures to follow mainstream ways to become a member of the new society. From a self reflectiveperspectivein this articlel show that the dynamics of social and cultural interaction create multipleparadoxes that transform the ways identities are developed, created and even invented in the process of migration and settlement. From my own experience as a recent 'ethnic' migrant in Australia, I will focus on some strategies developed by diasporic communities to define themselves by making borders and identities fuzzier, and 'playing' representations to manipulate ideologies. Through my personal gaze I will question rigid representations of Mexicanness and Mexican culture and emphasise the paradoxical outcome that, instead of borders defining identities, identities simultaneously create new borders and break others.
Geographic borders between countries set limits to the space, physical and social, where the notions of national culture and identity are created, transmitted, used and transformed. This process is basic for the construction of social and ideological collective actions, in which each individual identifies with and is identified as part of the group, building collective representations to differentiate them from others. These identities are dynamic, always in the process of 'construction of meaning on the basis of a cultural attribute, or related sets of cultural attributes, that is/ are given priority over other sources of meaning'. ${ }^{1}$ These representations serve to construct relations of cohesion or differentiation. They are not essences but are defined in cultural and historical terms, and create different narratives around specific concrete events, functioning to construct relationships, actual and potential.

The multiple possibilities of cultural representations of identities are internalised and used consciously or unconsciously in everyday life. They are also constructed through the continuous ideological meanings transmitted by the different state apparatuses, such as the school, by hegemonic discourses, the church and the media. They also evolve 
and change in dialogic interaction with others, those who share some of the meanings and those who are outside the borders, but still in some kind of interaction.

Borders, however, are much more than the geographical delimitations of a territory, and the experience of borders 'can happen whenever and wherever two or more cultures meet peacefully or violently'. ${ }^{2}$ Borders, from being concrete, crisp markers of different countries, national cultures, languages, become virtual, symbolic and therefore mobile. They appear each timean interaction with others happens, each time individuals represent the distinctiveness of their culture. In social interactions borders are not so rigid, and meanings flow through more or less easily, depending on the conditions and the issues that are negotiated in each exchange. As communication happens between two parties (by any means) dialogue makes borders fuzzy, transforming them into spaces for contact, into inter-zones for co-construction of meaning. In this senseborders simultaneously separate and bond.

In contemporary society the intercultural negotiation of identities has become everywhere an everyday experience. Whether it results from migration, travelling for pleasure, business or through use of global means of communication, in all cases the representation of identities varies depending on the kind of interaction, its political or ideological function, and the context of the encounter. In each case individuals, as social actors, activatetheir repertoire of cultural meanings from the country of origin and from their experiences of other cultures, to express their cultural values, their interest in other languages, their social experience and historical knowledge. All theseresources, which are shared in some degree by others from thesame country or from the new environment, areused in interaction to construct solidarity or mark difference. In someways each intercultural exchange implies a kind of 'journey' where the meanings of cultures and identities are carried into different contexts to negotiate, reinforce or transform the position of each one in the new context of interaction. In the case of migration, which is the specific focus of this article, the journey involves crossing physical borders to be outside one's own country, and to go into other cultures.

Journeys in this case are not only subjective but concrete displacements in time and space. They may be diasporas, with no immediate return, forming or entering new communities inside other larger communities. Diasporas 'constitute routes and roots, forms of community and solidarity outside of the time and national space with the aim to be inside [another country and culture] but keeping the difference'. ${ }^{3}$ Diasporic communities create forms of organisation and identity which build more or less rigid borders around them to emphasise their difference, in language or culture. Inside those borders diasporic communities recreate a culture and identity which is related to thecultureof origin but evolves in new ways to relate to thenew external environment. Diasporic communities use every resource to survive collectively in adverse conditions, reproducing, transforming and inventing specific forms of identity to make clear their distinctiveness, creating 'resistance identities' as cohesive strategies against the risk of cultural disappearance under the pressures of assimilation, or against a disadvantaged position in a country dominated by one culture-languagerace. $^{4}$ 
Sharing meanings as part of a diasporic community may help makethe process of settlement easier. Communication flows inside the community, with fewer risks of misunderstandings, or that is what it is commonly believed. In consequence, if you are in an alien environment you try to find spaces where there are common meanings to communicate, to feel 'safe' insidetheborders of communities created by other migrants. In general, the more you share the more you feel part of a collective, so you are able to belong, although this belonging carries therisk of not-belonging to the community of destination, not to be accepted by the 'other'. Migration brings a permanent dilemma, a continual need to make choices and travel through borders, avoiding crisp barriers, selecting how and where to belong.

Inside the borders built by diaspora communities in the new environment are the ones who hold membership, who share the place of birth, the culture, the language, the religion, the race, and the fact that they are all aliens to those outside. Insidethey form asocial network that works as a reci procal support for all, increasing the possibilities for each to succeed in the place of residency, and perhaps, of nationality. Legal and 'undocumented' migrant Mexicans in the US are in this category. Mexicans in the US form networks to support each other, to get jobs, to guide newcomers in understanding the new environment, although in the US, many Mexicans resist being nationalised as if their M exicanness were at risk. Apparently, to become 'gringo' is seen by other M exicanson both sides of the border as a betrayal.

Thesefeelings represent the dilemma which is part of the dynamic experience of migration: moving from one country to another, leaving one culture to understand and fit in another, learning a language feeling that maybe you will never feel sufficiently competent and at the same time fearing to lose spontaneity in your first language. The feelings of betrayal are captured in songs; for example in the song ' $M$ is dos patrias' (My two fatherlands) from a famous group in Mexico and the US, Los Tigres del N orte. Its Iyrics express clearly the dilemma for migrants who decide to acquire a new nationality, and the social pressures to which they are exposed. In this song the change of nationality is seen as a threat to the identity of the country of origin:

To the ones who call me anti-Mexican and betrayer of my nation and my flag And to break the frontiers with my song, I will open completely my heart. I left the tombs of my parents and grandparents, I arrived crying to the land of Anglo-Saxons.

I worked while my children grew, all of them born in this great nation

But my rights have been trampled on by the change of laws in the constitution What will I do if when I'm old they take all my money? I only want my insurance and pension.

What's the matter if I am now an American citizen, I'm still Mexican, like pulque and nopal

To defend the rights of my race my brothers, Central and South Americans, Caribbeans or Cubans have tropical blood

There is space for two countries in one heart.

The day of the oath of allegiance the judge stood up in the court.

My heart was crying with salt tears, which burned inside me.

Two flags troubled me. One green, 
white and red, with the eagle in the centre

The other with its blue full of stars, with red and white bars, of my children, who happily gazed at me.

Do not call me a betrayer. I love my two fatherlands.

In one I left my dead ones, and my children grew up here.

I cannot be a betrayer for defending my own rights. ${ }^{5}$

This dilemma does not al ways create such conflicts as in the case of Mexican immigrants in theUS, whereintercultural interaction triggers complex meanings and ideologies from a long, complex relationship that historically includes a vastly unequal power relationship between the country of origin and the 'host' country, which in this case is not very welcoming. ${ }^{6}$ In other countries where the relationship is less close and conflictual, citizenship is a practical option, less threatening to the original identity, especially as dual nationality is increasingly accepted in many countries, including Mexico.

\section{MY JOURNEY OF IDENTITY}

Asa Mexican, living in Mexico all my life, borders weremore or less clear and rigid. I lived inside the territory of Mexico, surrounded by the Gulf of Mexico, the Pacific Ocean, the Rio Bravo between Mexico and the United States and the border between Mexico and Central America. I also lived inside the borders created by a language, Spanish, which restricts the possibilities of interaction with speakers of other languages, but simultaneously creates a wide language community, which includes all Hispanic
America and Spain. The border of language in Mexico is also ideological: Spanish means non-English, nonamericanUS. ${ }^{7}$ I also lived in a culture which is simultaneously Western and notWestern. Likeall cultures, the Mexican is not homogeneous nor static, but a culture in process. Nevertheless it is represented in interactions as clearly distinct from other cultures, emphasising elements that aremorepositive and distinctiveto show its unique character.

The uniqueness of a culture, especially in a context of continuous intercultural exchanges, as has been the case in Mexican culture, is represented through images constructed from inside the country and also in a dialogic process with external understandings. These images are full of stereotypes, imagined representations and contradictions that have been used and developed at different moments of history, in interactions with other nations and cultures. One nuclear part of Mexican identity is its indianness. As a historic fact Indian peoples and Mesoamerican civilisations are the original inhabitants and cultures of the territory now called Mexico. Spanish culture and people are also part of the history. The encounters between Spanish and Indigenous peoples, as conflict or mestizaje ('mixing'), arepart of what all Mexicans know and share as our history. M exicanness comes from the mixing of two cultures that have interacted for more than 500 years, reproducing, resisting, transforming and creating new meanings, represented in customs, and cultural products. ${ }^{8}$ Although the culture has continuously changed some representations produced by this multicultural exchange have been used by some groups to construct symbols of Mexican identity. What was 
a vital identity in thepast has been frozen so it can function as the 'official', public representation of Mexicanness, in stereotypical symbols of Mexican culture and national identity.

In this context some elements come to mind in trying to define Mexicanness:

- prehispanic monuments;

- colourful handicrafts;

- beautiful embroidered clothes;

- the Mexican hat (sombrero de charro);

- traditional musicians (los mariachis);

- cultural events, such as Las Posada, with their piñatas, or the Day of the Dead with its skulls of sugar and paper skeletons;

- Mexican food: mole, tacos, chile, atole, tamales etc. ${ }^{9}$

Other elements of identity come from a shared knowledge of history, or histories, the most relevant in my view being:

- Independence Day, celebrated in all central plazas as EI Grito;

- Religious beliefs associated with manifestations of the Guadalupe Virgin to an Indian.

Thosefeatures of Mexican identity are familiar to everyone in Mexico and to many outside. Some are still important as signs of Mexicanness and used by many M exican people of all ages on some occasions. But their significance changes when they are embedded in intercultural and international interaction, used to represent Mexicanness to outsiders and to sell Mexico as a tourist commodity. Within Mexico, some of those features as they appear in everyday lifeare regarded as markers of class. They are associated with Indians, with poverty in rural life and urban popular culture. They areseen as kitsch in the houses of AmericanUS or Europeans who live in M exico, but signs of low class and bad taste in the houses of lower-class M exicans.

Six years ago I decided to come to Australia for professional and personal reasons. I knew I was beginning a journey across borders, but at that moment did not expect a transformation of identities. The first border was inside M exico City, the Australian Embassy, a nice, spacious building in Polanco, one of the greenest and wealthiest neighbourhoods of the city. The first things I saw when entering the room were some beautiful Mimi figures, as good as any I have seen in any museum in Australia. In the rear was a big window wherel could seea nice, well cared for internal garden. I became captivated, wanting to come as soon as possible to see more - more of the culture of Aboriginal people, more of Australia's natural wonders. That was the image the embassy was offering so successfully. Then I went to the visa desk. No one else was applying for a visa. It was a very strangefeeling as weM exicans are so used to making queues; this was a bonus, building a sense of what it would be like to move from one of the biggest cities of the world whose population is greater than the whole of Australia.

Applying for my visa I suddenly became part of the South A merican block, with its capital in Chile. Australia abroad is organised in regional divisions. As the officer explained, Mexico belongs to the South A merican region and everything is managed from the centre, located in Chile. As a consequence, I becamea South American, implicitly viewed with suspicion as a potential illegal, a potentially sick person wanting to get free medical treatment, likely to be a political refugee, a traumatised survivor from a dictatorship or from the drug wars. Nothing was making sense for me. I just 
wanted to come to study with an Australian scholarship I had won, living on my salary from a Research Centre in Mexico. In the Australian Embassy to be 'South American' means that you need to be well off to deserve an Australian visa: you need a house, car, credit card, US dollars, a permanent job, university fees and medical insurance. In one sense they wereright, I was a potential migrant, but not of the kind that immigration fears, aiming to stay illegally or become another burden for the welfare system.

After a month filling in forms, getting letters to probe my economic sustainability, medical exams and my return ticket (for a four-year program?), I got the visa and boarded the plane to cross other borders. One was the language, Australian English, completely incomprehensible, very little to do with what I learned in the classroom of AmericanUSlanguageschools in Mexico. Then I arrived at another border, the Immigration desk at the airport of Sydney. Having crossed theborder of the embassy, the airport one was easy, although I never understood, partly because of my insufficient English, and partly because of ignorance, why the immigration official looked at me with suspicion about the 'contradiction' of coming from M exico while saying no to the question about whether in the last month I had been in A frica, A sia or South America.

Later I realised that according to Australian cartography, Mexico is in South America. It was not only the product of Australia's rationalisation of its embassies overseas, as I had thought in Mexico. For Australians, Mexico is in South A merica, and not in North America as I learned when I was at school. Coming to Australia suddenly the borders changed, and the Rio Bravo, the border between Mexico and the United States, becamethe border between the $\mathrm{N}$ orth and the South, between the First and Third Worlds, between English and Spanish. This surely comes from the meaning of the same border in the AmericanUS imagination, in which theborder between Mexico and UShas mythical implications of national security. This border is where the Third World begins, the separation between N orth and South..$^{10}$ M exico is part of North America in the NAFTA agreement, but still in the South. I still have not learned that lesson, or maybe I do not want to learn it. When I am asked if I am from South America I say spontaneously "No'. I am beginning to answer, after some hesitation, 'From Mexico', but never 'Yes'.

During my lifein Australia, studying at an Australian university, learning to speak and writein another language, and living with an Australian I became more conscious about the differences and similarities, activating new skills to respond to the demands of social interculturality. To be a Mexican outside M exico, in my casein Australia, demands some behaviours that are considered proper for a Mexican. Suddenly I needed more knowledge about Mexico, its history, economy, folklore, politics and all its tourist destinations, from beaches to colonial cities, and of course prehispanic sites. I was required to be a Mexican expert on all issues related to the specialisation of people I was interacting with. At the same time I needed to simplify the realities of my country. A gainst my preference to look for diversity I was pushed to build a more or less homogenous Mexico, though I resisted reducing it entirely to stereotypes. I also felt the duty to show a more 
accurate understanding of the aspects that are regarded as signs of M exicanness. Thepressures of being in another country were transforming my Mexicanness, trying to look 'more respectable' for foreign eyes than the type of Mexican I am in contemporary AmericanUSised Mexico.

A nother featureadded to my identity in Australia was ethnicity. Here I am 'ethnic'. Given that the word 'ethnic' refers to the fact that 'each of us is shaped by and towards the culture in which we are born', ${ }^{11}$ everybody is an 'ethnic'. However, 'ethnic, as a label, has tended to be attached to the periphery or margin by thewestern viewpoint of modernity'. ${ }^{12}$ 'Ethnic' is used to refer to traditional cultures that areconsidered in someways as 'primitive'. In Australia to bean ethnic minority is to be the other, the alien. $\mathrm{N}$ ot all migrants are 'ethnic': the term is applied to those who are different compared to the cultural features of mainstream Australia, of AngloAustralia.

Officially, I am 'ethnic' becausel have a non-English language background (NESB), because I speak English as a second language. I am an ESL person. In this sensel sharean identity with Chinese, Sri Lankans, Indonesian, Italians, Greeks, Maltese, Bulgarians, Russians, French, Filipinos etc. I do not know however if all these groups would like to be part of this big community. Actually this shared identity is not even an 'imagined community', it is just unreal, but virtually it divides the world in two, 'primitives' and English speakers.

To be an ethnic in this sense imposes some borders that need to be crossed. Australia's multiculturalism and equal opportunity provisions do not save people from the disadvantage of being from another linguistic group. English is the dominant language that you need to learn to interact in everyday life, to study, to get a job. This border is as fuzzy as other borders and some accents, some mixes of languages are more acceptable than others. I guess many other ideological and political aspects are involved, but I haven't experienced clearly theimposition of astrict linguistic border. My accent is more or less accepted, I believe, ${ }^{13}$ and the reactions I have experienced to my accent focus on its unfamiliarity which frequently leads to question about my country of origin. My answer almost always provokes the comment: 'Oh! how interesting', a positive new feature to include in my identity. In Australia I have an 'interesting' identity, and I suppose I will not lose it as probably I will never lose my accent.

There are not many Mexicans in Australia: around 500, according to the Mexican Embassy list. There is an association in Sydney, the Mexican Australian Welfare Association Incorporated (MAWAI), a diasporic 'ethnic' community with highly fuzzy boundaries, which consists 'of people of Mexican descent, Mexicans who live in Australia, friends of Mexicans and anyone interested in Mexico or Mexican Culture. ${ }^{14}$ From this list it is clear that this diasporic community is very open, very inclusive. According to their self representation the 'aim of this community is to make Mexicans residing in A ustralia ... feel less lonely and not too far from their own families, customs, food and traditions'.15

In many ways my experience as migrant is not typical compared to the experience of other migrants who form diasporic communities such as the 
MAWAI. I have not tried to be part of the Mexican community in Australia, probably because I have not felt the need to belong to that kind of community to survive as an alien or to get support from others who might understand me better because of the shared cultural identity. I haven't felt al oneamong Australians, nor thought that sharing with other M exicans will makemeless sad at being so far from my family, and from friends in Mexico, many of whom come from other countries, as is common now in increasingly multicultural cities.

Communities in diasporas develop forms of identities, making the representation of the diasporic identity of Mexicansimportant in relation to thenew environment. Therepresented identity of the diasporic community expresses in some ways 'authentic' Mexicanness in Australia, which is visiblein the web page of the association. In it you can find written and visual texts connected to the events that Mexicans celebrate in Australia, which include traditional cultural and patriotic representations of Mexicanness: flags, folkloric dances, piñatas, calaveras (skeletons and skulls), sombreros de charro (the Mexican Hat) (Figure1). Theonly event not of this kind was a bush walk, which may be related to the Australianisation of the Mexican community, or a common activity in many cities where peoplego out to escape from urban stress, or maybe a nostalgic connection with rural life in their place of origin. I have not researched the relevance of this event for M exicans, but I can see in it the potential sign of paradoxes of diasporic identities, as the simultaneity of contrasting representations in dialogue with the new environment. Still, Mexican hats, singers and guitars were there.
As is common in representations of identities in social interaction, ${ }^{16}$ the public image of theassociation selects theimages to be shown from a wider range of cultural practices and actual events which contain a more complex expression of culture and identity. Comparing the images displayed in the web page from the Independence Day party in 2001 with the same event in 2002, which I attended, I was able to see, and feel, a M exicanness that is closer to my experiencein M exico. The actual party to celebrate Mexican independence brought together some signs of tradition with transnational representations of the culture, which would not beseen as M exican but feel like 'being in Mexico'. As a whole this event was different to what I was expecting from the images shown on the web page, which represented a very M exican community. On the web page the images of a Mexican celebration look more stereotypical than the way they are performed in Mexico, very close to a tourist performance: folkloric dances; Mexican hats and Mariachis; and green, whiteand red decorations with flags and china paper. In the actual event there were other aspects that were unexpected and less 'Mexican'.

I would liketo comparenow thesame event as it happens in Mexico. Independence day in Mexico, called EI Grito, is one of the occasions when Mexican food must beincluded. Tostadas, tacos and pozole are the most common in every house that day, and they are sold in the streets around the different plazas. But in thecelebration in Australia theonly Mexican food was a chilli sauce with corn chips as an entrée. Themusic was mixed, including some traditional Mexican music that drove me back to my teenage years, and contemporary dance music, 

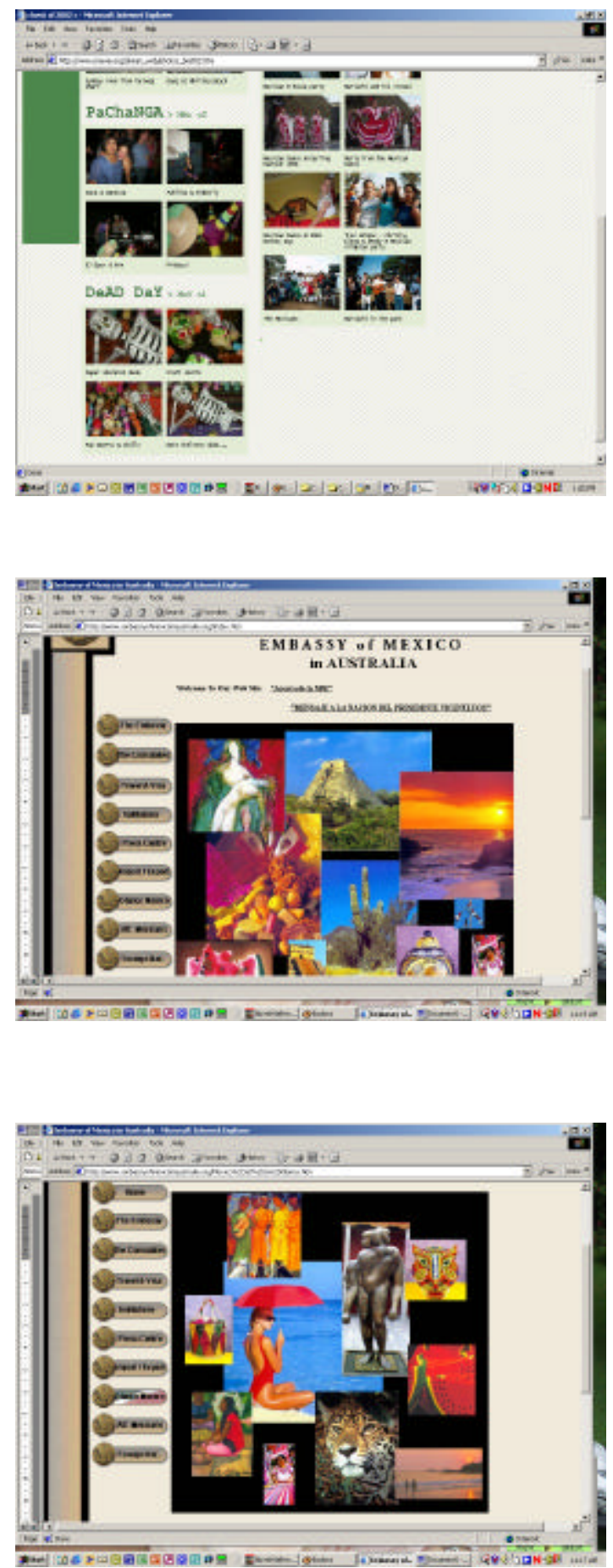

Figure 1

MWAI web page, accessed October 2003

Figure 2

Embassy of Mexico in Australia web page, www.embassyof mexicoinaustralia.org accessed October 2002

Figure 3

Embassy of Mexico in Australia web page, www.embassyof mexicoinaustralia.org accessed October 2002 
the same kind you can hear in any party in Mexico, some in English, others in Spanish. Overall theweb pagelooks more Mexican than the same event in Mexico but theAustralian event was less Mexican than the same celebration in Mexico. Paradoxically it had the same feeling as being in Mexico, but in a non 'Mexican' party. The common symbol in the three representations is the flag with its three colours, green, white and red. It is the patriotic national sign that seems unchanged by the diasporic experience.

From this experiencel am able to see the doublerepresentation of M exicanness, one more public, more expected by Australians, the other more private, shared with friends from other Latin American or Australian communities. In the 'private' one everyone brings memories from their time in Mexico or from their last visit, a typical item of clothing, a flag, the new CD played on the radio stations there or a loved disc that has just been recorded in the new $C D$ format. In that sense the diasporic community provides two forms of Mexicanness, which are linked and used both to relate to the new country and to keep the continuity of identity with the country of origin.

Other representations of 'authentic Mexicanness', which are accessible outside Mexico and generate some expectations among Australians, come from discourses of tourism, which transform people and culture into commodities, and al so feed the images of national identities in a stereotypical way. To find how this kind of representation was constructed for A ustralians I looked at the M exican Embassy web page. In my view this page reflects tourist representations of Mexico, which have some affinities with the Mexican identity in diaspora as depicted on the Mexican Association web page. The representations of Mexicanness on the main page consist mainly of pictures, a collage of colourful images of art, prehispanic monuments, tradition, handicrafts and nature (Figure 2). Similar images are repeated in the link 'Glance Mexico' which in two pages brings together the past and the present, culture and wilderness. What was surprising in 'Glance Mexico' was the central image, a tall tanned blonde woman sitting on a beach, protecting herself from the sun with an umbrella (Figure 3). Strangely, this is the only representation of people in the Mexican embassy's image of Mexico, and she is surely not Mexican. In this case the embassy has selected only aM exico for therich. I hopethis web page is not the main source of the M exicanness that Australians expect, as I would not be able to meet their expectations.

\section{MIGRATING MEXICANNESS}

My experience with other migrants (living in Mexico or in Australia), especially after many years outside their countries, reminds me of what is called the aestheticisation of identities, which appears as the 'kitsch effect' and a proliferation of stereotypes. ${ }^{17} \mathrm{~A}$ common strategy of diasporic communities is to 'make up' the culture, as a means of interacting with others, negotiating an image that gives them importance and value, even by 'inventing' traditions derived from local customs or events but appropriated and transformed in thenew environment. I have been impressed by houses of Mexicans who have lived outside Mexico for a long time. In one of them, where I was invited to a party, all elements of M exicanness wereon display. 
There was not any doubt that it was the houseof a Mexican. AsI remember it this house was full of traditional objects that used to be common in Mexico. Maybe they are still used in some houses, but they are mainly stored and replaced by modern objects which fulfil similar functions (e.g. blenders instead of molcajetes, traditional stone mortars). These items, such as cazuelas (clay pots), canastas (baskets), plaits of garlic, mazorcas (cobs of corn), cebollas derabo (onions with long leaves), were in this house objects of decoration. The set of china we ate from was a 'set of Mexico' made of clay, and we drank tequila in typical goblets of Mexican blown glass. On the walls were some paintings in the style of Diego Rivera and Frieda Kahlo, all full of colour, hanging on white walls with blue bands, azul colonial, the same blue as was used in old $\mathrm{H}$ aciendas (colonial estates) or 'typically Mexican' restaurants.

I have also seen the sadness of migrants getting back to their birthplace to find that their memories have betrayed them and the culture is as alien to them as they arealiens to the people from their country. Their identity is no longer a shared identity. The culture has been changing in a way that has not been experienced by the diasporic culture. In some ways, to get back is also an experience of crossing new borders, now inside the so-called same culture. After crossing the national border, other borders are created, a border between the living culture and themythical culture of diasporas.

After six years living in A ustralia with continuous trips to Mexico, my ways of representing my Mexicanness have changed in some of the directions that are reported about other diasporicidentities. This is despite my conscious attempts to fight the essentialisation of my culture and its nostal gic mystification, including my use of the Internet to bein continuous contact with Mexican culture and its transformations.

My experience as described in this paper is not representative of other people's Mexicanness, although I believe it is not so atypical. For example, one major cause of migration to Austral ia for Mexicans, as in my case, has been a love relationship, and this helps explain why the Mexican diasporic community in Australia has fuzzier borders than other diasporic communities. My identity outside Mexico is probably going through similar processes, developing someforms of invented and fragmented identity, not unlike the experiences of fragmentation and cultural mixing in other instances of diasporic experience, as in the US, where the biggest Mexican diaspora is. My identity in A ustralia has been influenced by the diasporic representation of Mexicanness hereand in other countries. Even though I do not fit clearly the definition of a migrant in a diaspora, I consider my current identity a diasporic identity in process.

\section{INVENTING MY MEXICANNESS}

As a middle-class woman I grew up eating tortillas but I never made them; I atemole but, to prepare it, usually to serve it as an offering to foreign friends, I bought a paste packed by a national or multinational business, which made it very easy to prepare. Mainly because I am an anthropologist, I sometimes dressed in Indian clothes in my youth, and decorated my house, much to the shame of my family, with handicrafts. I al ways liked Mexican music but I was regarded as old fashioned, part of the 
minority who chose Latin American folk instead of rock and roll. I never owned or used a charro, a hat; I prefer the more practical palm hats to protect mefrom the sun. Even now my daughters do not forgive me for sending them on school trips with beautiful peasant hats instead of a cap, una cachucha, like all the other children. And to my shame the first time I went to hear El Grito in Mexico City, it was becausemy daughters werewanting to share that event with their diasporic Argentinean friends.

From this account of my connections with Mexicanness, I was a very poor Mexican, but simultaneously I was as Mexican as the majority of people in Mexico and, in comparison with some, even more so. Now, after crossing the border to leave my country and become Australian, I can see myself doing things that are reported as common tendencies of diasporic behaviour, showing off my Mexicanness. ${ }^{18}$ Recently for the first time in my life I made some tortillas, real tortillas of white corn I found in a shop which imports exotic products, and I prepared an 'authentic' molewith red dry capsicum for Australian tastes, not hot but with the sameflavour as 'chileancho'. In my first trip back to Mexico I brought back my Indian clothes (from my anthropologist identity), which had been stored in a trunk sincel was 25 -years-old, used a few times in fancy dress parties. I use them now when I want to represent my new Mexican identity. In my last time living in Mexico, before I came definitively to work and live in Australia, I bought for the first timein my lifea set of colourful Mexican china, de Talavera (of thetype that, according to the removalist company, every Mexican from the embassy brings). I also bought an image of the GuadalupeVirgin which is hanging in my bedroom, and a Mexican flag, to wave on the day of El Grito.

I am not sure if this means crossing borders or creating borders, maybeboth. The dynamics of the diasporic experience in my view imply a continuous movement of being inside and outside, of belonging and being excluded, of crossing some borders and building others. To be a Mexican outside Mexico and insideM Mexican culture, it is necessary to become an expert in crossing borders and performing identities, using, transforming and inventing new identities that look 'interesting', 'traditional', 'ethnic', 'authentic', 'aesthetic', 'kitsch'. These are identities which are co-constructed from the self and the other. In Australia I am more 'authentically' Mexican than in Mexico, and therefore my identity as diasporic Mexican is as Australian as it is Mexican.

\section{ENDNOTES}

1 M. Castells, The Power of Identity. The Information Age: Economy, Society and Culture (London: Blackwell Publishers, 1997, II) p. 6.

2 Gómez-Peña in C. Fusco, 'The Border Art Workshop/ Taller de Arte Fronterizo: Interview with Guillermo Gómez-Peña \& Emily Hicks', in Third Text 7, Summer 1989: 53-76, p. 113.

3 'Conforma rutas y raíces, formas de comunidad y solidaridad fuera del tiempo y el espacio nacional, con el propósito de estar adentro [de otro país y cultura] pero manteniendo la diferencia'. My translation from M.A. Rodríguez, $M$ ito, identidad y rito: $M$ exicanos y Chicanos en California, (México: CIESAS, Editorial Porrúa, 1998) p. 249. 
4 Castells, The Power of Identity; Rodriguez, M ito, identidad y rito.

5 Para quien dice yo soy un malinchista y que traiciono a mi bandera y mi nación Para que rompa con mi canto las fronteras les voy a abrir de par en par mi corazón.

D eje las tumbas de mis padres, mis abuelos. Llegué llorando a tierra de anglosajón. Yo trabajaba, mis hijos iban creciendo. Todos nacieron bajo de esta gran nación Y mis derechos los han ido pisoteando, van formulando leyes de constitución Q ue haré ya viejo si me quitan mi dinero; yo sólo quiero mi seguro de pensión Pero que importa si soy nuevo ciudadano sigo siendo M exicano como el pulque y el nopal

Y mis hermanos centro y sudamericanos, caribeños o cubanos

traen la sangre tropical para que respeten los derechos de mi raza

Caben dos patrias en el mismo corazón

El juez se paró en la corte la tarde del juramento

De mi corazón brotaba una lágrima salada que me quemaba por dentro

D os banderas me turbaban, una verde, blanca y roja con el águila estampada La otra con su azul Ileno de estrellas, con sus rayas rojas y blancas grabadas,

La bandera de mis hijos que alegres me contemplaban.

No me llamen traicionero, que a mis dos patrias las quiero

En la mía dejé a mis muertos. A quí mis hijos nacieron.

Por defender mis derechos no puedo ser traicionero.

6 See Castañeda, 'La Encrucijada Migratoria México-Estados Unidos', in The Estados U nidos Affair, (México: Aguilar, 1996) pp. 63-103.

7 I use the term AmericanUS, AmericanUSAcion etc. to avoid the ideological sense perceived by Latin American people as imperialism, when 'American' is used to refer only to the people of United States of America. Used in this way, 'American' excludes everyone else from the 'American' continent.

8 G. Bonfil, México Profundo: U na Civilización N egada, (México: SEP/ CIESAS, 1987).

9 There are other dishes associated with Mexican food that come from the external construction embodied in 'Tex Mex' food, which multinational food chains spread globally.

10 Gómez-Peña, in Fusco,'The Border Art Workshop'.

11 F. Mackie, 'The Ethnic Self', in A. Kellehear, ed., Social Self, Global Culture: An Introduction to Sociological Ideas, (Oxford: Oxford University Press 1996, 34-44) p. 35.

12 Mackie, 'The Ethnic Self', p. 40.

13 The only occasion when I felt rejection of my English was in a phone interaction, which makes me think that maybe the fact that I do not look racially so different protects me from rejection, from being seen as having 'a strong accent'.

14 http:/ / www.homestead.com/ mawai/ information ns4.html

15 http:/ / www.homestead.com/ mawai/ information ns4.html

16 See E. Goffman, The Presentation of the Self in Everyday Life, (London: Penguin, 1976).

17 Rodríguez, M ito, identidad y rito.

18 See C. Velez-Ibañez, Visiones de frontera: Las culturas mexicanas del sureste de Estados U nidos, (México: CIESAS/ Porrúa, 1999). 